\title{
ECOLOGICAL UNITY AND POLITICAL FRAGMENTATION: THE IMPLICATIONS OF THE BRUNDTLAND REPORT FOR THE CANADIAN CONSTITUTIONAL ORDER
}

\author{
MARK WALTERS*
}

\begin{abstract}
Using the recommendations of the Brundtland Report and the "Green Report" of the Canadian Council of Resource and Environment Ministers as a basis for analysis, the author discusses Canadian environmental policy and natural resources management within a constitutional setting. The author asserts that by failing to expressly address the constitutional implications that these issues raise, namely, that the natural environment must be conceptualized as a cohesive unity which renders political boundaries mere legal fictions, the approach to date has been fundamentally flawed. Part One of the paper sets out the principles of sustainable development and the constitutional questions they raise for Canadian resource management and Canadian federalism. Part Two then examines the "spillover" theory of democracy and federalism and its relationship to the "Peace, Order and Good Government" clause. The author concludes that a formalistic Constitutional framework can never provide a practical solution to the problem environmental management and resource management are indivisible and should be addressed through cooperative federalism. Finally, the author suggests that the Constitution may be able to play a constructive role by defining the parameters within which cooperative federalism must occur.
\end{abstract}

En s'appuyant sur les recommandations du Rapport Brundtland et du "Plan vert" du Conseil canadien des ministres des ressources et de l'environnement, l'auteur examine la politique canadienne relative d l'environnement et a la gestion des ressources naturelles dans un cadre constitutionnel. L'auteur affirme que, en s'abstenant de traiter expressément des implications constitutionnelles de ces questions - c'est-d-dire que l'environnement naturel doit être perçu comme une unité cohésive, qui transforme les frontieres politiques en notions juridiques relevant de la pure fiction. l'approche adoptée jusqu'ici comporte une faille fondamentale. La première partie du présent article énonce les principes de développement durable et les questions constitutionnelles qu'ils soulèvent en termes de gestion des ressources canadiennes et de fédéralisme canadien. La deuxième partie examine la théorie de "débordement" [spillover] de la démocratie et du fédéralisme, et ses liens avec la clause de "la paix, l'ordre et le bon gouvernement". L'auteur conclut qu'un cadre constitutionnel formaliste ne pourra jamais offrir une solution pratique au probleme; la gestion de l'environnement et des ressources étant indivisibles, elles doivent être abordées dans le cadre d'un fédéralisme coopératif. Finalement, l'auteur suggère que la Constitution pourrait jouer un rôle constructif en définissant les paramètres à l'intérieur desquels ce fédéralisme coopératif doit prendre forme.

\section{TABLE OF CONTENTS}

I. INTRODUCTION $\ldots \ldots \ldots \ldots \ldots \ldots \ldots \ldots \ldots \ldots \ldots$

II. PART ONE: THE BRUNDTLAND REPORT

AND THE CANADIAN CONSTITUTION $\ldots \ldots \ldots \ldots \ldots \ldots$

III. PART TWO: ENVIRONMENTAL EXTERNALITIES AND

THE PEACE, ORDER AND GOOD GOVERNMENT POWER . . . . .

IV. CONCLUSION

LL.B. Queen's University, presently doing graduate work in law at University College, Oxford. The author wishes to thank John Whyte, Dean of the Queen's Faculty of Law, and Carol Creighton, Constitutional Law and Policy Division, Ministry of the Attomey-General, Ontario, for their assistance. 


\section{INTRODUCTION}

The official response of the Canadian government to the recommendations of the Brundtland Report' has been, at least in rhetoric, swift. Within months of the Brundtland Report's release, the National Task Force on Environment and Economy, established by the Canadian Council of Resource and Environment Ministers (CCREM), produced its own "Green Report."2 Inspired by the Brundtland Report, it purports to embrace the concept of sustainable development - integration of resource, industrial and environmental planning must now be the guiding light for all government policy.

Unfortunately, the Green Report is naively (or deliberately) silent with respect to the constitutional problems which will, as will be argued in this paper, arise as Canada moves to confront the challenge of sustainable development. The Green Report introduces a system of "Round Tables" designed to provide forums within each province and at a national level for implementing sustainable development. Says the Task Force:

The Round Tables will bring together senior decision makers to advise First Ministers and other national leaders on the coordination and harmonization of actions to promote environmentally sustainable economic development in Canada. The Round Tables are an innovative Canadian approach. ${ }^{3}$

The Progressive Conservative government of Brian Mulroney has adopted the Round Table approach as the path to fulfilling the goals of the Brundtland Report in Canada. ${ }^{4}$

While the Round Tables are no doubt "innovative," they remain, as the Task Force says, distinctly "Canadian". They are the embodiment of a particularly Canadian attitude toward federalism, namely, that of cooperative federalism. These Round Tables will have no inherent or delegated legislative power, no authority to bind provincial or federal governments or even private entities; they will be, as their label suggests, tables of bargaining and therefore of compromise. It is the tendency of any regime of cooperative federalism to marginalize the normative value of the Constitution. In essence, by omitting to address expressly the constitutional implications which the challenge of sustainable development presents for Canadian federalism, the Green Report follows this path and, consequently, is fundamentally flawed, or at least incomplete, as a guide for future policy formation for resource management.

The World Commission on Environment and Development, Our Common Future (Oxford: Oxford University Press, 1987).

2. Report of National Task Force on Environment and Economy (Canadian Council of Resource and Environmental Ministers, September 24, 1987). The much anticipated federal "Green Plan" released March 29, 1990, turned out to be a rather vague discussion paper: R. Howard, "Green Plan Draft Disappoints Groups", Globe and Mail (21 August 1990) A4.

3. Progress Report of National Task Force on Environment and Economy (Canadian Council of Resource and Environmental Ministers, October, 1988), p. 3.

4. The Prime Minister announced the creation of the National Round Table on the Environment and the Economy on March 29, 1989. See Cleroux, "Major Groups not Included in Round Table," Globe and Mail (29 March 1989) A5. 
It would be incorrect to say that the federal government has taken no legislative steps toward the goal of sustainable development, for the Canadian Environmental Protection $A c t^{5}$ (the "CEPA") can be seen as such a step. Although mainly a consolidation of previously existing legisiation, ${ }^{6}$ the CEPA also contains new, and potentially far-reaching, provisions on toxic substance management." Unlike the "Green Report," the CEPA does at least advert to the constitutional problems of environmental regulation; ${ }^{8}$ but the CEPA's answer to these constitutional problems apparently involves, not unlike the approach taken in the "Green Report," resort to the federal-provincial bargaining table.'

This paper is premised upon the notion that a coherent strategy of sustainable development must be developed within a principled context founded upon the Constitution. Principle, of course, is not an end to itself and certainly it will not be argued that there is anything intrinsically prophetic in the text of the Constitution Act 1867. It will be argued, however, that the presently evolving ecological context, as charted by the Brundtland Report, challenges the essence of Canadian federalism and, consequently, demands a re-evaluation of the principles underlying the Constitution. If interjurisidictional cooperation is necessary - and no doubt it is - the resiliency of the ideals of federalism and democracy within which this cooperation occurs is contingent upon a clear definition of the constitutional responsibilities of federal and provincial governments over natural resources and the environment.

While a comprehensive definition of a constitutional plan for the future in this respect is beyond the scope of this paper, some of the main issues and challenges to be addressed will be raised. At the heart of the dilemma which the evolving ecological and resource management "crisis" presents for our constitutional order is the underlying message of the Brundtland Report, namely, that ultimately the natural environment must be conceptualized as a cohesive unity which renders political boundaries mere legal fictions. As fictional as boundaries may be, in a physical sense they do create political

5.

S.C.-1988, c. 22.

The CEPA repeals various statutes and then incorporates their provisions into a comprehensive act. For example, Part III of the CEPA ("Nutrients") is a reenactment of Part III of the Canada Water Act, R.S.C. 1985, c. C-11; Part IV ("Federal Departments") is similar to the s. 12 of the Clean Air Act, R.S.C. 1985, c. C-32; Part V ("International Air Pollution") resembles ss. 23 and 24 of the Clean Air Act, Part VI ("Ocean Dumping") is a reenactment of the Ocean Dumping Control Act, R.S.C. 1985 , c. 0-2; Part II of the CEPA ("Toxic Substances") broadens significantly provisions previously found in the Environmental Contaminants Act, R.S.C. 1985, c. E-1.

7. The provisions in the CEPA purport to regulate all aspects of toxic waste management, apparently whether their potential for harm is local or national in scope.

Section 34 (6) of the CEPA provides for operation of those provincial laws which are equivalent to federal standards. And, s. 6(1) contemplates federal-provincial committees designed to eliminate federal and provincial conflicts in environmental regulation. Also, the preamble of the CEPA is apparently framed to support a "Peace, Order and good Government" argument in any future constitutional challenge. It reads in part: "Whereas the presence of toxic substances in the environment is a matter of national concem," and " Whereas toxic substances, once introduced into the environment, cannot always be contained within geographic boundaries."

See s. 6 (1) of the CEPA. 
constituencies, they determine which people will manage which natural resources, and, having been drawn over the face of the world in disregard for the patterns of ecosystems which sustain life, political boundaries create problems. As the Brundtland Report says, "[t]he enforcement of the common interest often suffers because areas of political jurisdictions and areas of impact do not coincide."10 As a federal state, Canada is put into a paradoxical position when confronting this phenomenon: while it can re-constitute itself so that those who manage resources and those affected by the environmental side-effects of this management are one and the same, ${ }^{1}$ to do so may equate to the negation of federalism.

In short, if the challenge of sustainable development is to be met successfully, it must be seen as more than a challenge to our conceptions of economic production and consumption; it must be seen as a challenge to our present vision of federalism and democracy and, consequently, as a challenge to the role of the Constitution within that vision.

In approaching this issue, this paper proceeds in two parts. In part one, the themes and principles of sustainable development, as enunciated by the Brundtland Report, are set out along with the constitutional questions they raise for Canadian resource management and Canadian federalism. Part two examines one specific question in detail, namely, the "spillover" theory of democracy and federalism and its relationship to the "Peace, Order and good Government" clause of the Constitution Act, 1867. It will be suggested that recent interpretations of the p.o.g.g. power are paradigmatic of the general challenge which sustainable development presents for Canadian federalism. ${ }^{12}$

\section{PART ONE: THE BRUNDTLAND REPORT AND THE CANADIAN CONSTITUTION}

The Brundtland Report describes sustainable development as economic development which "meets the needs of the present without compromising the ability of future

10. See Our Common Future, supra, note 1 at 47.

11. See, general discussion on the "spillover" theory of federalism, Richard Simeon, "Criteria for Choice in Federal Systems" (1983) 8 Queen's L.J. 131 at 144.

12. In focusing on the division of federal and provincial powers over natural resources and the environment this paper is, of course, incomplete. As the questions of Aboriginal Title and sovereignty are fully worked out, there will no doubt be a third governmental dimension to resource and environmental issues. Indeed, the agreements in principle reached in respect of northern land claims incorporate innovative mechanisms, like resource management boards, in order to accommodate Aboriginal participation in the decisions affecting northem resource development. See for example, DeneWeris Comprehensive Land Claim Agreement in Principle (Canada: Indian and Northem Affairs, September 1988) and Council for Yukon Indians Comprehensive Land Claims Agreement in Principle (Canada: Indian and Northern Affairs, May 1987); and, in general, see, William Sinclair, ed. Native Self-Reliance Through Resource Development, Proceedings of the International Conference Towards Native Self-Reliance, Renewable Development (Vancouver: July, 1985). 
generations to meet their own needs."13 In charting the "new context" in which economic and resource development must occur, the Brundtland Report can hardly be said to have created the concept of sustainable development. In fact, a variety of national and international documents have previously advocated the same principle under different labels. ${ }^{14}$ However, for the purposes of this discussion, the Brundtland Report, as the latest and perhaps most comprehensive treatment of the matter, is selected as setting out the basic tenets of a sustainable development strategy. Seven such tenets are set out below with reference to the particular constitutional dilemmas they raise for Canadian natural resource management and Canadian federalism. The seven tenets do not coincide with the format of the Report itself; they are merely a summary of its general themes and recommendations.

"Ecology and economy," says the Brundtland Report," are becoming ever more interwoven - locally, regionally, nationally, and globally - into a seamless net of causes and effects." 15 This is the central message of the Report and, hence, the first tenet of sustainable development to be discussed. From this recognition of the interrelated nature of the environment and the economy flows the "chief institutional challenge" issued to the world by the Report: those responsible for formulating policies with respect to the economy, trade, taxation, industry, investment and all other matters, including the management of natural resources, must be made responsible for the environmental issues related to their respective areas of decision-making. ${ }^{16}$ The task implies ending the fragmentation of environmental regulation from regulation of all other elements of our public and private activities.

In denying the desirability of consolidating responsibility over the environment within one governmental department, there is an implication that, likewise, this responsibility cannot be consolidated within any one level of government. In a federal state, then, there must be a decentralization of power over the environment such that each level of government can ensure that the resource and environmental issues related to each of its traditional spheres of constitutional jurisdiction are taken into account in the course of policy formation.

This institutional recommendation apparently meets little constitutional resistance in Canada. There would have been a constitutional impediment to the de-fragmentation of environmental regulation had exclusive legislative power over "the environment" been allocated to the federal legislature (even so, the doctrine of delegation could then have been invoked), but such is not the case. The Constitution Act, 1867 is silent as to the

See Our Common Future, supra, note 1 at 8.

See for example, the United Nations "World Conservation Strategy" summarized in Allen, How to Save the World (Scarborough: Prentice-Hill Lid., 1980) and for a Canadian perspective, Royal Commission on the Economic Union and Development Prospects for Canada (Ottawa: Minister of Supply and Services, 1985), Vol. II, p. 526.

See Our Common Future, supra, note 1 at 5.

Ibid. at 313. 
environment per $\mathrm{se}^{17}$ and, as a consequence, both Parliament and provincial legislatures have taken steps to regulate the management of the environment.

Given the all-pervasive nature of environmental management, it is difficult to conceive of one level of government as having exclusive power over it - indeed, to confer exclusive jurisdiction over sustainable development would be like conferring a legislative monopoly over common sense to one level of government. In addressing this issue, the MacGuigan Report concluded that the scope of environmental management is virtually endless, touching upon, among other matters, pollution control, land use control, control of mining, lumber, wildlife, fish, agriculture, transportation, electric power, water management, housing, and urban planning. ${ }^{18}$ As such, the MacGuigan Report rejected the idea that environmental management could be dealt with under one new constitutional head of power. ${ }^{19}$ Indeed, it has been suggested that a constitution which purported to confer such an expansive power on one level of government would cease to be truly federal. ${ }^{20}$

Thus, in its failure to allocate power over the environment to any one level of government, the Constitution has permitted each level of government to legislate in this field - and this apparently accords well with the institutional requirement of sustainable development. In Canada, "the managers of renewable resources," one study concludes, have, since 1971, been entrusted "with the responsibility to protect the relevant environment of each resource". ${ }^{21}$ This is precisely what the Brundtland Report recommends.

Upon closer scrutiny, however, there are two aspects of the Constitution which threaten to frustrate the attainment of the institutional requirement of sustainable development. The first is the potential scope of federal legislative jurisdiction over environmental matters under the "Peace, Order, and good Government" clause of section 91 of the Constitution Act, 1867. The problem is that the more environmental issues are dealt with federally under the p.o.g.g. clause, the more a sense of fragmentation will exist between environmental decision-making and resource management by provinces. The potential scope of the p.o.g.g. power is very broad. At least one judge has held there to be an exclusive federal power, by virtue of the p.o.g.g. clause, over both intra- and inter-

17. No doubt because environmental issues were not of pressing political concern in 1867: Nemetz, "The Fisheries Act and Federal - Provincial Regulations: Duplication or Complimentarity?" (1986) 29 Can. Pub. Admin. 401, at 402.

18. Canada, Parliament, Special Joint Committee of the Senate and the House of Commons on the Constitution of Canada, Final Report (Ottawa: Queen's Printer, 1972), pp. 90-2.

19. Ibid.

20. Dale Gibson, "Constitutional Jurisdiction over Environmental Management in Canada" (1973) 23 U.T.L.J. 54, at 85.

21. Improved Program Delivery, Environmental Quality Strategy Review, A Follow-On Report of the Task Force on Program Review (Ottawa: Ministry of Supply and Services, 1986) at 51. 
provincial environmental issues; but, this decision was soon overturned. ${ }^{22}$ Nevertheless, recent judicial decisions indicate the expansiveness of this general power of Parliament. The nature of its role is therefore considered separately in Part Two of this paper.

The second aspect of the Constitution which may inhibit the consolidation of resource management and environmental protection policy formation is the constitutional allocation of legislative jurisdiction and ownership rights over natural resources. If the consolidation of policy formation is to occur, the power to deal with the relevant environmental issues connected with each resource must follow the power to manage each resource. This in turn necessitates a coherent allocation of legislative responsibilities over resources to begin with. For the purposes of instituting policies of sustainable development, this coherence may be lacking in the Constitution. The problem stems from the fact that provinces own many of their resources, but the federal Parliament has legislative authority over some of them. This fact is the source of much jurisdictional confusion. ${ }^{23}$

Section 109 of the Constitution Act, 1867 provides that all "Lands, Mines, Minerals, and Royalties" situated within the boundaries of the original provinces of confederation belong to those provinces. The Constitution Act, $1930^{24}$ places the prairie provinces in the same position. The reference to "Lands" has been held to include resources incidental to the land, like fishing and timber rights. ${ }^{25}$ In the past there has been a difference of interpretation as to the extent of the provinces' constitutional powers as proprietors of resources. The central question relates to whether ownership of resources confers a super-added power on provinces such that, in managing these resources, respect need not be given to spheres of federal constitutional jurisdiction unless valid conflicting federal law happened to be in place. Those heads of power under section 91 which would most obviously constrain the provinces in their management policies include, section 91(2) Trade and Commerce, section 91(10) Navigation and Shipping, section 91(12) Sea Coast and Inland Fisheries, section 91(24) Indians and Lands reserved for the Indians, section 91(27) Criminal Law and, potentially, the peace, order and good government clause.

The generally accepted view is that provinces have at least as extensive management latitude with respect to the resources they own as does any private owner. ${ }^{26}$ In other words, through conditions in leases, control of Crown corporations and other examples

R. v. Lake Ontario Cement Ltd. (1973), 35 D.L.R. (3d) 109 (Ont. H.C.) overturning Clendenning Prov. C. J.'s decision at 10 C.C.C. (2d) 141. Jim MacNeill, Environmental Management: A Constitutional Study Prepared for the Government of Canada (Ottawa: Information Canada, 1971).

24. 21 Geo. V, c.-26 (U.K.).

25. A.G. Canada v. A.G. Ontario, Quebec, Nova Scotia (Fisheries Reference), [1898] A.C. 700 and for comments in this respect, Crommelin, "Jurisdiction over Onshore Oil and Gas in Canada" (1975) 10 U.B.C.L. Rev. 86 at 102.

26. W. Moull, "Natural Resources: Provincial Proprietary Rights" (1983) 21 Alta. L. Rev. 472 at 481. See also J.0. Saunders, "Canadian Federalism and International Management of Natural Resources" in J.O. Saunders, ed., Managing Resources in a Federal State (Toronto: Carswell, 1986) at 274. 
of executive prerogative, it has been suggested that provinces can do that which through legislation they may be precluded from doing by virtue of sections 91 and 92 .

Extreme variations exist on this interpretation of the Constitution; ${ }^{27}$ however, even if the most narrow interpretation is adopted, the fact of ownership coupled with legislative competence over the "Management and Sale of the Public Lands Belonging to the Province and of Timber and Wood Thereon" (section 92(5)), "Local Works and Undertakings" (section 92(10)), "Property and Civil Rights" (section 92(13)), "all matters of a merely local or private nature" (section 92(16)) and, as of 1982, the "development, conservation and management of non-renewable natural resources and forestry resources in the province" (section 92A(1)) equips provinces with an adequate constitutional basis upon which to enact the sort of legislation contemplated under a sustainable development strategy. As long as provincial legislation in this respect is correctly characterized as relating in pith and substance to the conservation of a resource, sensible management of a resource, or the control of the adverse environmental effects produced in the development of a resource then, notwithstanding any incidental impact on federal heads of power, the legislation will be held valid. The provincial power to conserve a publicly owned resource has long been judicially recognized. ${ }^{28}$ Likewise the provincial ability to regulate the negative environmental side effects of resource development has been judicially characterized as flowing from sections $92(13)$ and $92(16){ }^{29}$ This authority over conservation and resource management has been at least confirmed, if not extended, by the addition of section 92A into the Constitution Act, 1867 in 1982. While some observers contend that, from a conservation/environmental perspective, subsection $92 \mathrm{~A}(1)(\mathrm{b})$ merely restates expressly provincial powers which already existed impliedly, ${ }^{30}$ others claim this amendment is a significant change which expands provincial powers in this area and correspondingly diminishes the federal scope of authority under the peace, order and good government clause. ${ }^{31}$ The latter view is perhaps the better view. Insofar

n7. On the one hand, it is argued that provinces are constrained in their executive dealings with their property as they are in their legislative capacity: Bushnell, S.I., "Constitutional Law - Proprietary Rights and the Control of Natural Resources" (1980) 58 Can. Bar Rev. 157. On the other hand, westem provinces argue that, even in their legislative capacity, the fact of ownership means they are not constrained by section 91 unless valid conflicting federal legislation is in place. They rely on Smylie v. R. (1900) 27 O.A.R. 172 (Ont. C.A.); see Moull, supra, note 26.

Spooner Oils Ltd. v. Turner Valley Gas Conservation Board, [1933] S.C.R. 629, 4 D.L.R. 545. However, provinces are constitutionally constrained in conserving resource industries in the economic sense: Central Can. Potash Co. v. Saskatchewan, [1979] 6 W.W.R. 400, 88 D.L.R. (3d) 609. A question now arises, however, as to whether section $92 \mathrm{~A}(\mathrm{l})$ 's reference to "conservation" means physical conservation of resources or conservation in an economic sense. Likely it will be interpreted as meaning the former. See for comments on this issue, W. Moull, "Section 92A of the Constitution Act 1867" (1983) 61 Can. Bar Rev. 715 at 718.

29. $\quad$ R. v. Lake Ontario Cement Ltd., supra, note 22.

30. R. Caims, M. Chandler, W. Moull, "The Resource Amendment (Section 92A) and the Political Economy" (1985) 23 Osgoode Hall L.J. 253, at 270.

31. A.R. Lucas, "Harmonization of Federal and Provincial Environmental Policies: The Changing Legal and Policy Framework" in J.O. Saunders, ed., Managing Natural Resources in a Federal State (Toronto: Carswell, 1986) at 36. 
as legislation contemplated under a strategy of sustainable development goes, the presence of section 92A(1) now provides an inescapable textual signal which in effect announces clearly the proposition that, whatever reality the new context of sustainable development brings, and whatever corresponding challenges and ecological crises arise, federalism demands that provincial constituencies retain significant political control over their resources.

As mentioned, the Constitution may lack a sense of coherence with respect to the allocation of resource management powers. The source of this incoherence is that two levels of government may be involved in the regulation of various resources which occupy one environmental space. In this respect the p.o.g.g. clause, as noted, provides a flexible point of entry for Parliament in respect of provincially owned resources. By virtue of the p.o.g.g. clause Parliament may be able to regulate the management of interprovincial waters, ${ }^{32}$ emissions by industry into the atmosphere, ${ }^{33}$ and potentially any environmental matter for which there is provincial inability to regulate. ${ }^{34}$ In short, the scope is very broad.

Of the specific federal heads of power under section 91, that which may contribute most to the above-mentioned incoherence is section 91(12), the federal fisheries power. As noted by Ritchie, C.J., in $R$. v. Robertson, ${ }^{35}$ the federal power in relation to fisheries is not one of ownership, but is related "to subjects affecting the fisheries generally, tending to their regulation, protection, and preservation ..." In exercising this power, it was held that federal legislation "might very seriously touch the exercise of proprietary rights ..."36 Thus, as long as federal legislation in this respect refers expressly to the link between the regulated conduct and the well-being of fish, Parliament may incidentally influence the provincial management of logging ${ }^{37}$ and hydro-electric dams. ${ }^{38}$ Indeed, it has been said that section 33 of the federal Fisheries Act, ${ }^{39}$ which prohibits the dumping of "deleterious" substances into waters populated by fish, is one of the "most powerful environmental protection laws in Canada." ${ }^{.40}$

The allocation to the Parliament of the fisheries resource has been the subject of much criticism. It has been argued that the failure of Canada to develop a coherent forestry strategy is the result of jurisdictional rivalry produced by the collision of the federal fisheries power and provincial management of logging. ${ }^{41}$ Some observers call for a

Interprovincial Co-operatives v. Manitoba, [1976] 1 S.C.R. 477, 53 D.L.R. (3d) 321.

Re Canada Metal Co. Ltd. \& The Queen (1983), 144 D.L.R. (3d) 124 (Man. Q.B.).

$R$. v. Crown Zellerbach Canada Lid., [1988] 1 S.C.R. 401.

[1882] 6 S.C.R. 52 at 120.

Fisheries Reference, supra note 25 at 712.

Fowler v. The Queen, [1980] 2 S.C.R. 213.

A.G. Canada v. Aluminum Co. of Can. (1980), 115 D.L.R. (3d) 495 (B.C.S.C.).

Fisheries Act, R.S.C. 1970, c. F-14; now section 36(3) Fisheries Act R.S.C., 1985, c. F-14.

See $A$ Follow-On Report of the Task Force on Program Review, supra note 21 at 68.

F. Wetton, "Evolution of Forest Policies in Canada" (1978) 79 Jour. of Forestry 565. 
constitutional amendment placing fisheries in provincial hands; ${ }^{42}$ others call for the establishment through federal-provincial cooperation or, if necessary, unilaterally by Parliament under the p.o.g.g. clause, of "omnicompetent" river basin authorities. ${ }^{43}$

How does the constitutional division of powers in Canada stand up to the institutional challenge of the Brundtland Report? To summarize briefly, while there is no constitutional barrier per se to the goal under this first tenet of sustainable development to decentralize environmental regulation into the hands of resource managers so that environmental and resource development issues are addressed simultaneously, a coherent strategy of sustainable development presupposes a rational allocation of resource management authority between levels of government to begin with. The Brundtland Report speaks to the general barrier to sustainable development of departmental fragmentation over the environment and economic and resource development within the same level of government. Special concerns arise, however, in a federal state where, in essence, the fragmentation problem acquires a further, more deep-rooted dimension. In the case of fisheries and forestry, the environmental concerns of each are often unified yet the regulation of the environmental priorities of the former are constitutionally fragmented from the regulation of economic development priorities of the latter. In short, the Constitution, which on its face allows for the break-up of environmental decisions among levels of government, may in fact frustrate the goal of sustainable development on a different score, namely, through a division of resource jurisdictions in such a way which is insensitive to the singleness and unity of ecosystems. Thus, in Canada, the separation of economic and resource development decision-making from aspects of environmental decision-making is, in some areas, constitutionally entrenched and, hence, the challenge of the first tenet of sustainable development will be difficult to meet.

The second tenet of sustainable development makes a fundamental connection between the environmental soundness of economic development and democracy. The recommendation of the Brundtland Report in this respect is that the goal of sustainable development is contingent upon effective participation by citizens in the decision-making process. "The law alone cannot enforce the common interest," states the Report, "[i]t principally needs community knowledge and support, which entails greater public participation in the decisions that affect the environment. ${ }^{\text {"44 }}$ This, in turn, implies the need for improved public access to information and more effective channels for public input into policy formation.

R. Fashler \& A. Thompson, "Constitutional Change and the Forest Industry" in J. Beck \& I. Bemier, eds., Canada and the New Constitution, Vol. II. (Montreal: The Institute for Research on Public Policy, 1983) 55. The 1987 Meech Lake Constitutional Accord would have added s. 50 to the Constitution Act. 1982. Section 50 would have provided for annual constitutional conferences for first ministers to discuss, among other things, the "roles and responsibilities in relation to fisheries."

43. Gibson, "The Constitutional Context of Canadian Water Planning" (1969) 7 Alta. L. Rev. 71 at 86.

4. See Our Common Future, supra, note 1 at 63. 
The second tent of sustainable development creates serious constitutional implications for Canada. In a representative democracy, the Brundtland recommendation translates to the need for political openness and political accountability. Strong arguments can be made that the Constitution, instead of instilling a sense of rule of law into environment and resource management, suffocates the ideal with a fog of jurisdictional ambiguity, thereby frustrating the goals of openness and accountability. Public participation and interest group access to those who formulate policy requires a clear understanding by both those in power and those attempting to sway those in power of just who is responsible for what. In the area of environmental management, however, confusion prevails on the part of both officials and the public in this regard. ${ }^{45}$ The example of the fisheries/forestry ambiguity has been mentioned; indeed, in this respect Anthony Dorcey paints a picture of an almost daily scene in which federal fisheries officials and provincial forestry officials haggle at the edge of a stream over whether an onlooking logger should cut a nearby tree. ${ }^{46}$ This picture may not be far from the truth.

There are two opinions as to the effect of this constitutional ambiguity. First, there are those who decry the confusion on the grounds that it inhibits effective public participation, diminishes public visibility of policy formulation and, consequently, weakens political accountability for resource management decisions. Second, there are those who find a glimmer of benefit within the constitutional fog; it is said that as long as neither level of government knows precisely what it is responsible for neither will act unilaterally and, hence, an air of co-operation and a necessity for inter-governmental negotiation is fostered.

In general, there is a symbiotic relationship between environmental problems and democracy. While the solution to these problems may, as the Brundtland Report suggests, lie with more effective democracy, it has been suggested elsewhere that the very surfacing of environmental problems has spurred a greater demand for public consultation. ${ }^{47}$ As the public gains an awareness of how economic policies will affect them, the demand for a say in the policy formulation increases; the Berger Commission now stands as the classic example of the efforts made to seek out public opinion - in this case, that of remote native communities - as to the management of a resource. ${ }^{48}$

Nevertheless, both the MacGuigan Report of 1972 and the MacDonald Commission Report of 1985 emphasized how the Constitution plays an inhibiting role in this respect. The MacGuigan Report was concerned that, where environmental issues were being dealt with piecemeal through spheres of constitutional jurisdiction of which the parameters were unknown, the electorate would be unable to respond at the right time and with respect to

45.

46.

47.

48.

Follow-On Report of the Neilsen Task Force, supra note 21 at 111.

Anthony Dorcey, "Techniques for Joint Management of Natural Resources: Getting to 'Yes " in Managing Resources, supra note 26 at 19.

Robert Paehlke, "Democracy, Bureaucracy and Environmentalism" (1988) 10 Environ. Ethics 291. Mackenzie Valley Pipeline Inquiry, Northern Frontier/Northern Homeland (Ottawa: Ministry of Services, 1977). 
the right politicians when an environmental issue became an election issue. ${ }^{49}$ Environmental problems "do not always fit into such neat, compartmental packages [as fisheries, managing public lands, or navigation]," said the Report, "[c]onsequently, the lines of political accountability are not clear. The voter is left with his annoyance; the politician with his constitutional enigmas." ${ }^{\text {s0 }}$ The Report recommended a Constitutional amendment recognizing concurrent provincial-federal powers, with express federal paramountcy, over air and water pollution.

The MacDonald Commission Report focused on the procedural inhibitions to political accountability resulting from jurisdictional overlap on resource issues. It noted a "fragmentation" of the environmental impact assessment process, where for any one project there may be separate federal and provincial assessments and public hearings. ${ }^{51}$ This not only serves to "deflect attention from major issues" but it imposes high costs on public interest groups who struggle for membership due to free rider problems in the face of a cohesive, well-financed business voice. ${ }^{52}$

On the other side of the argument are those who perceive political benefits from constitutional confusion. The Neilson Task Force, for instance, recommended that it would be preferable to avoid a legal clarification of the "muddy" nature of jurisdictional lines in the resource and environmental management area - a judicial pronouncement would merely serve to antagonize federal-provincial relations and frustrate inter-governmental negotiation. ${ }^{53}$ In short, the general theme of the argument in favour of constitutional ambiguity is that it enhances co-operative federalism. ${ }^{54}$ The "political constitution," says A.R. Lucas, often renders the "legal constitution" superfluous. ${ }^{55}$ Both Lucas and Andrew Thompson point to the example of the Canada Water Act, ${ }^{56}$ which, if implemented fully, would allow for large, unilateral federal powers over the management of inter-jurisdictional rivers. ${ }^{57}$ The federal government has not proceeded unilaterally under the Act for fear of provincial challenges under the "legal constitution" (this, in spite of Pigeon J.'s judgment in Inter-Provincial Cooperatives) ${ }^{58}$ and also because of provincial "sensitivities," or, in other words, the constraints of the "political constitution." Federal-provincial bargaining has resulted instead. Similarly, under the

Joint Committee on the Constitution, supra note 18 at 91-94.

Ibid.

Royal Commission on the Economic Union, supra note 14 at 515.

Ibid.

Task Force on Program Review, Environment: Improved Program Delivery (Ottawa: Ministry of Supply and Services, 1986) at 25.

54. Lucas, supra note 31; and also Saunders, supra note 26 at 284.

5s. Lucas, supra note 31 at $34-5$.

56. R.S.C. 1985 , c. C-11.

57. Lucas, supra, note 31 and Andrew Thompson, Environmental Regulation in Canada (Vancouver: Westwater, 1980).

58. Interprovincial Cooperatives, supra note 32. However, the federal government has been judicially prompted to carry out environmental assessments of dams on rivers: for example, Cdn. Wildlife Federation Inc. v. Canada (Minister of the Environment) (1989), 3 C.E.L.R. (N.S.) 1 (Fed. C.A.).
} 
federal Fisheries Act, the federal government has not exercised its apparent full constitutional authority and has instead negotiated some standards (as with respect to the pulp and paper industry $)^{59}$ and has delegated the setting of others to the provinces. ${ }^{60}$

It must be concluded that, at least on the environmental regulation side of resource management (the revenue and royalty side is a different story), constitutional ambiguity has indeed fostered a sense of federal-provincial cooperation. In the context of assessing the Constitution's role within the process of implementing strategies of sustainable development, however, this may not be a helpful state to be in. The second recommendation thusfar drawn from the Brundtland Report - that democracy needs to be improved and that lines of public access to those officials making decisions need to be opened - challenges the notion that this constitutional ambiguity and the accompanying cooperative federalism is in the best interests of sustainable development. Cooperative federalism may serve to preclude the sort of fierce federal-provincial conflict experienced in relation to oil and gas revenues in the late 1970s and early 1980s, but it must be questioned whether this peace is a worthy end in itself; and, if indeed it is, whether it ought to be sought at the expense of political accountability and effective public knowledge and participation in the policy making processes.

It has been suggested that cooperative federalism is nothing other than executive federalism. ${ }^{61}$ "Executive federalism," is, in turn, associated with backroom collusion, not open democracy. ${ }^{62}$ Notes Richard Simeon, it usually follows constitutional confusion as to which level of government is responsible for a certain matter, and the ensuing private inter-jurisdictional negotiation leaves little room for informed citizen participation. $^{63}$ Environmental management in Canada apparently fits this model at present.

To a certain degree, then, conflict may be beneficial. ${ }^{64}$ This is not to say that constitutional lines must be drawn as battle lines and open war declared. Cooperative federalism itself is not to be feared, rather, it is cooperation and negotiation within the

For a list of federal-provincial agreements thus far concluded for setting standards, see the Follow-On Report, Neilson Task Force, supra note 21 at 69.

60. For example, pursuant to regulations made under the federal Fisheries Act (Ontario Fishing Regulations C.R.C. Vol. III, c.849) Ontario's game and fish licensing machinery is adopted and Ontario's Minister of Natural Resources has been delegated quota setting powers. This quota setting has been done through Ontario's Game and Fish Act, R.S.O. 1980 c.182. The Supreme Court of Canada has upheld this delegation as valid and not as a delegation of legislative powers, despite the Ontario Minister's rather wide scope in setting fishing quotas. See Re Peralta et al \& The Queen in Rt. of Ontario (1985), 49 O.R. (2d) 705 (Ont. C.A.) affirmed without reasons (S.C.C., Dec. 15, 1988).

61. Albert Breton, "Supplementary to Natural Resources and the Environment" Royal Commission on the Economic Union, supra, note 14, Vol. III, at 493.

62. Ibid.

63. Simeon, supra note 11 at 152.

64. Breton, supra note 61 at 492; Roy Romanow, "Federalism and Resource Management," in Managing Resources, supra note 26 at 9. 
context of ill-defined constitutional responsibilities which threatens to inhibit Canada's achievement of the second Brundtland tenet. Only upon a clearer understanding of constitutional responsibilities can the Canadian public hope to enjoy the supposed ideal of the rule of law. In failing to recognize this point, the Green Report is weakened substantially in its attempt to usher in a strategy of sustainable development for Canada.

The democracy theme of the Brundtland Report raises another, more substantive resource management issue for the federal state, namely, the question of which constituency, regional or national, ought to control the management of which natural resources. In essence, the hope for public participation and political accountability is dashed if the environmental problems facing one political community flow from resource development which is managed by another political community. One solution, which is in itself a recurring theme throughout the Brundtland Report, is the suggestion that each individual political unit take into account the adverse environmental externalities it produces and minimize them. ${ }^{65}$

As idealistic as this suggestion seems it is in fact the only answer to the externalities problem which exists on the international dimension. On the domestic scale, however, it can be assumed that a federal state is capable of re-constituting itself so that those affected by the environmental aspects of resource and industrial development are those who manage the development.

This theory of federalism is compelling; it accords well with fundamental notions of democracy. Faith need not be placed in the hope that a province will consider the common interest of all before developing a resource which will produce extrajurisdictional side effects, for the Constitution would be fashioned in such a way that, as Simeon says, "[t]he jurisdiction for a given policy [would] precisely coincide with the set of people affected by it...there [would] be no spillovers... ."66

Phrased in an alternative way, the "spillover" theory of federalism is simply the idea that local constituencies deal with local issues and national constituencies deal with national issues. The ability of federalism to embody this ideal has led many observers to conclude that, especially for an expansive, geographically diverse nation like Canada, it is the ideal form of political ordering for resource and environmental management. ${ }^{67}$ Jurisdiction over resource management can be premised upon the resources' supposed "spatial quality"68 -that is, the allocation of authority as between local or national constituencies would simply depend upon the "territorial ramifications"

65. Brundtland Report, supra note 1 at 87.

66. Simeon, supra note 11 , at 144.

67. MacNeill, supra note 23 at 9-11; Thompson, supra note 57; Lucas, supra note 31 at 33.

68. Lucas, supra note 31 at 33.

69. Gibson, "Environmental Protection and Enhancement under a New Canadian Constitution," in Canada and The New Constitution, supra note 42 at 119. 
MacNeill captures the essence of the "spillover" theory of federalism by setting out three classes of resource management scenarios: first, that where the source and the effect of the environmental problem are internal to the jurisdiction; second, that where the source is internal, but the effect is external; and, third, that where the source is external and the effect is internal. ${ }^{70}$ In scenario three, the government of the jurisdiction will lack the political power to deal with the issue; meanwhile, in scenario two, the government will lack the political incentive to manage the resource more sensibly. In scenario one, however, both ingredients are present. Under the "spillover" theory of federalism the local government would manage the issue in the first scenario whereas the central government would manage the problem in the other two instances.

To what extent does the Canadian Constitution parallel the spillover theory of federalism? Indeed, to what extent should it parallel this theory of federalism? These are perhaps the most fundamental constitutional questions raised by the challenge of sustainable development and, hence, are addressed in Part Two.

If constitutional lines of jurisdiction can be fashioned within a federal state so as to promote a more effective sense of democracy by limiting the degree of externalities, the same cannot be said with respect to political lines of jurisdiction internationally. Instead, faith must be put in the "common interest" ideal expressed by the Brundtland Report namely, that sovereign states will conform to policies of economic development and trade which best accord with an international strategy of sustainable development. To this end, the third theme which can be drawn from the Brundtland Report concerns the need for increased international cooperation between sovereign states. "No country can develop in isolation from others," says the Report, "[h]ence the pursuit of sustainable development requires a new orientation in international relations." 71 Given the increasingly "porous" nature of national boundaries, a vast increase in the number of treaties and conventions can be expected if a world-wide strategy of sustainable development is to be initiated.

This requirement of sustainable development raises particular problems for Canadian federalism. No doubt, most of these treaties will touch upon matters traditionally seen as falling within provincial authority, including natural resources owned by provinces. If the present constitutional arrangement in relation to treaty negotiation and implementation has, as has been suggested, "impaired Canada's capacity to play a full role in international affairs, ${ }^{172}$ then, given the inevitable need for international coherence and planning in the economic, trade and resource policies of individual states, ought the constitutional restraint presently placed on the Canadian Parliament in implementing treaties be removed? This dilemma represents just one more form in which the principles embodied in the concept of sustainable development challenge the essence of Canadian federalism.

\footnotetext{
70. MacNeill, supra note 23 at 16.

71. Brundtland Report, supra note 1 at 40.

7. Peter Hogg, Constitutional Law of Canada 2nd ed. (Toronto: Carswell Co., 1985) at 253.
} 
If Canada is committed to the ideal of federalism, the answer must be no. At present, only the federal executive can enter into binding international commitments on behalf of Canada. ${ }^{73}$ Although section 132 of the Constitution Act, 1867 hints at a federal ability to implement treaties through legislation regardless of whether the substance of the treaty relates to section 92 or not, the Labour Conventions Case $^{74}$ holds the contrary: the "water tight compartments" of legislative jurisdictions are retained as Canada's ship sails into international seas. In other words, for Canada's commitments internationally to have any legal meaning domestically, the provinces must assent to them insofar as they touch upon matters of provincial constitutional competence.

The practical result has been that the federal government has sought provincial support for its foreign policies in advance of entering into international commitments. The political leverage which a province can exert on the federal government in this respect can be great, as evidenced by British Columbia's insistence upon changes being made in the 1961 Canada-United States Columbia River Treaty. ${ }^{75}$ Today, provinces participate on the numerous water management boards, like the "Great Lakes Water Quality Board," established under the Canada-United States "Boundary Waters Treaty" (1909) which address the common concerns of the two countries relating to rivers and lakes spanning the boarder between them. ${ }^{76}$

The possibility of a province opting out, or refusing to participate in, a resource management regime which Parliament has enacted as its part in an international plan pursuant to an international treaty is of some concern. In such a case, parochial interests would be, apparently, thwarting the ambitions of the world community. Nevertheless, if Canada's commitment to federalism is genuine, then its commitment to international sustainable development need not force an alteration of the present treaty power under the Constitution. For instance, should Canada enter into a treaty accelerating the bans on the production of chloroflourocarbons (CFB's) only to find the major producer of CFB's in Canada, Ontario, refused to support the treaty, and if Parliament nevertheless passed implementation legislation purporting to ban CFB production in Ontario, any subsequent judicial characterization of the law would resemble the typical consideration of impugned legislation passed by Parliament on its own initiative, without the impetus of a treaty. In other words, if a national concern, or a national emergency, were found to exist (a fact no doubt evidenced by the treaty) the legislation would stand as valid under the p.o.g.g. power. If not, then the legislation would be ultra vires and would fall. There being no

73. Ref. re Offshore Mineral Rights, [1967] S.C.R. 792, at 817. Even so, provinces regularly enter "non-binding" international agreements; for instance there are seventy-nine agreements on natural resources and the environment between Michigan and individual provinces: Saunders, supra note 26, at 275.

A.G. Canada v. A.G. Ontario, [1937] A.C. 326, at 354. There have, however, been subtle hints in recent decisions that this rule may be subject to re-consideration: John Whyte, "Federal Powers over the Economy: Finding New Jurisdictional Room" (1987) 13 Can. Bus. L.J. 257, at 291.

75. Neil A. Swainson, Conflict over the Columbia (Montreal: McGill-Queen's University Press, 1979), and Saunders, supra note 26 at 278.

76. Royal Commission on the Economic Union, supra note 14, Vol. II, at 520-2. 
treaty power per se, the p.o.g.g. power becomes the most logical federal head of power under which treaty implementation legislation could be passed. For this reason, the treaty issue ultimately dissolves into a p.o.g.g. issue and whatever theory of p.o.g.g. accepted will apply to the treaty implementation issue.

The fourth tenet of sustainable development to be drawn from the Brundtland Report concerns social and economic equity. The Commission found that "[p]overty is a major cause and effect of global environmental problems." 77 Derived from the fact that underdeveloped peoples and countries are forced to plunder their own resources in order to survive is the conclusion that sustainable development can only be achieved if poorer regions of the world are placed on some sort of par with the developed regions in terms of basic necessities of life.

The principle of social and economic equity contains valuable messages for Canada, for within Canada's federal structure there are "have" and "have-not" regions. If the ingredient of social equity is essential to the success of sustainable development internationally, then no doubt it is essential within Canada itself. The Brundtland message in this respect is somewhat paradoxical; on the one hand, it observes that poorer regions always over-exploit and mismanage their resources (in order to pay foreign debts and to survive); and, on the other hand, it concludes that these regions must nevertheless keep exploiting their resources in order to develop and break the vicious cycle of ecological suicide and poverty. The key, it says, is adopting a coherent plan of resource development with "slower growth combined with re-distribution in favour of the poor,"78 and, also, massive outside help. On the dimension of Canadian federalism, then, the concerns are identical: the poorer provinces may be more tempted to over-exploit their resources, and hence outside help, in the form of federal aid, is required.

Traditionally, provinces have perceived their natural resources as potential springboards to economic prosperity and government revenue. Garth Stevenson notes that section 109's location within the Constitution Act 1867 in "Part VIII - Revenues; Debts; Assets; Taxation" is of strategic meaning. ${ }^{79}$ Likewise, the Judicial Committee of the Privy Council noted in 1882 that the "general subject of the whole section [109] is of high political nature. It is the attribution of royal territorial rights for the purposes of revenue... 1180

The Brundtland Report too perceives resources as the foundation for necessary development; the problem, however, is the temptation on the part of weaker regions, or provinces, to maximize present returns from their resources to the detriment of the future

77. Brundtland Report, supra note 1 at 3.

78. Ibid. at 52.

79. Cited in Caims et al, supra note 30 at 255.

80. A.G. Ontario v. Mercer (1882) 8 A.C. 767 at 779. 
generations. ${ }^{81}$ The MacGuigan Report, in making its recommendation for a constitutional amendment relating to concurrent provincial-federal jurisdiction over air and water pollution, argued that it was "only recognizing the obvious" (namely, this "temptation" of "weaker" provinces to be less vigilant in resource management) when it recommended federal paramountcy be expressly recognized. ${ }^{82}$

Thus, "destructive, competitive bidding for industrial development" ${ }^{183}$ on the part of some provinces is a concern. A solution which involved decreasing provincial control over resources on these grounds would not be consistent with the ideal of federalism. A better solution may already be located in the constitution. Part III of the Constitution Act, 1982, section 36, provides inter alia that Parliament and the provincial legislatures are committed to "furthering economic development to reduce disparity..." and Parliament is committed "to the principle of making equalization payments..." This essentially entrenches within Canada's Constitution the principles of regional and social equity which are, according to the Brundtland Report, crucial to the initiation of sustainable development. In addition to this express constitutional obligation, the implied federal spending power is important in this respect. The federal government can simultaneously increase the economic well-being of provinces and decrease any over-exploitation of natural resources through creative, bilateral or national funding programmes in which, by way of the spending power, financial resources are forwarded to provinces in return for their compliance in regional or national sustainable development strategies, strategies which the federal government might otherwise lack legislative competence to enact by statute.

The fifth theme to be drawn from the Brundtland Report concerns, at least implicity, the relationship between law and values. The Report concludes that sustainable development is contingent upon a change in values which amounts to no less than a fundamental re-structuring of life styles in the developed world. It phrases the point in this way: "Perceived needs are socially and culturally determined, and sustainable development requires the promotion of values that encourage consumption standards that are within the bounds of the ecological possible and to which all can reasonably aspire..." ${ }^{184}$

The concern that politicians, in both rich and poor regions, will maximize present returns to the detriment of the environment is common. It has been said that it is "almost irresistible to a "four year politician " to overuse resources and the environment: Paul Emond, "Cooperation in Nature: A New Foundation for Environmental Law" (1984) 22 Osgoode H.L.J. 323, at 336.

82. Joint Committee on the Constitution, supra, note 18 at 92 . Of course, it should be recognized that, as with the developed nations worldwide, the richer provinces are rich in large part because they have an abundance of natural resources. Environmental degradation often flows from exploitation of marginal natural resources. Thus, as in the international context, in Canada, the claim is strong that a portion of riches earned from sustainable development of natural resources in privileged regions should flow to poorer regions so that the pressure on poorer regions to exploit marginal resources is lessened.

83. Nemetz, supra note 17 at 413-4.

84. Brundtland Report, supra note 1 at 44. 
Western culture is no doubt instilled with a hierarchical vision of the world in which natural resources exist to satisfy present human desires. This philosophy pervades the law from the nineteenth century courts of equity ${ }^{85}$ to twentieth century environmental protection statutes. ${ }^{86}$ This is to be contrasted with the law of traditional North American native communities, for example, which reflects a political morality in which a non-hierarchical attitude transcends all facets of the community down to its vision of natural resources. "The Creator, in granting land," says one native writer, "did not give the land to human beings only but gave it to all living beings. This includes plants, sometimes rocks, and all animals. ${ }^{187}$ It has been suggested that our managers of natural resources, in striving to adopt policies of sustainable development, could learn much from native Canadians. ${ }^{88}$

In general, a community's culture - its moral, social and political morality - changes gradually and symbiotically with evolving internal and external challenges and demands. The role which law plays in the process is the subject of a constant, on-going discourse among legal and social science scholars. One can ask, for instance, whether law has an instrumental effect, such that upon being legislated into existence it proceeds to shape and mould values in new directions through its administration and enforcement; or, whether, on the contrary, it merely reflects the a priori political and social culture of the community.

This issue is of particular significance for the question of the Canadian Constitution's role within the context of sustainable development. In one sense, the Constitution, as embodying a past commitment to federalism, will play a conservative role, forcing the legal reform which will accompany sustainable development down certain normative paths. The normative power of the Constitution Act, 1867 in this sense, however, is procedural not substantive; it relates to jurisdiction, to the question of which level of government will do what. However, the question of cultural change raised by the challenge of sustainable development leads to the question of what normative force the Constitution can, or should, have on substantive law reform.

From an instrumentalist perspective, the Constitution may be capable of participating in the change of societal values required for sustainable development. It has been

85. Fletcher v. Bealy (1885), 28 Ch. D. 688 illustrates the prevalent attitude that minor amounts of environmental damage can always be fixed later, here, an application for a quia timet injunction to prevent the dumping of chemicals into the Thames River was dismissed because the environmental damage would not be felt for ten years and, said the court, "I think that in ten years time it is highly probable that science...may have discovered some means for rendering this green liquid innocuous." Emond notes that Ontario's environmental protection statutes are "utilitarian, not utopian" aimed at keeping environmental destruction within reasonable limits thereby reinforcing the hierarchical attitude of people over "things." Emond, supra note 81.

87. Leroy Little Bear quoted in Aboriginal Peoples and the Law, Bradford Morse, ed. (Ottawa: Carleton Univ. Pres, 1985), at 50.

88. David Suzuki, "Resource Managers can learn from ways of Native People," in Globe and Mail (11 March 1989) D4. 
suggested by Colin Stevenson that a constitutional amendment, perhaps to the Charter of Rights and Freedoms, entrenching as a fundamental human right the right to a safe and healthy environment would serve this end. ${ }^{89}$ Such an entrenchment, it is argued, may give "moral authority" to environmental rights, thereby forging an "environmental ethic." 90 In giving courts a foundation upon which arguments against the traditional legal conceptions of property could be accepted, an educational function would ultimately be performed. ${ }^{91}$

The express recognition in law of a fundamental human right to a safe and healthy environment can be seen as a means toward the end of changing values. However, more importantly it represents an end in itself. Indeed, it is a separate recommendation of the Brundtland Report. The Report notes that, after the Stockholm Declaration in $1972^{92}$ which provided that everyone "has the fundamental right to freedom, equality and adequate conditions of life, in an environment of a quality that permits a life of dignity and well being," several states entrenched an environmental right in their constitutions. While the Report concedes that a constitutional entrenchment may not be appropriate in all countries, the law of all nations, it says, should recognize in some way, perhaps through ombudsmen or special councils, such a basic human right. ${ }^{93}$

In Canada, numerous constitutional amendments aimed at entrenching an environmental right have been suggested, ranging from a detailed "environmental bill of rights" more vague, sweeping Charter-like statements. ${ }^{95}$ In considering the context of our constitutional legal regime in general, these proposals are not radical or alien to our larger sense of legal rights. Our political morality already contains what MacNeill calls the "cardinal liberal tenet" that people not be adversely affected by the "spillovers" of the activities of others. ${ }^{96}$ The law of nuisance comes to mind in this respect.

In one sense, then, what is needed is a re-constitution of values - a "newly constituted reality" ${ }^{177}$ - so that the legal regime we live in perceives the relationship between

89.

9. Dean Whyte uses this expression to describe the shift in fundamental values which precedes shifts in constitutional jurisprudence, supra note 74 at 260 . 
economic development on the one hand and natural resources on the other in a radically different light. This newly constituted reality, however, need not be divorced from the past commitments of our present constituted reality. The normative power of the constitutional regime of today - which is reflected by documents like the Charter ensures that the substantive law reform required by the concept of sustainable development need not break new paths through unknown territory, for the necessary foundation of legal rights already exists waiting to be extrapolated to fit the new context. Of course, the task could be made substantially easier if our "positive law," i.e., our constitutional documents and our judicial pronouncements, expressly recognized the specific right to a safe and healthy environment which, it may be argued, exists presently in our "full law.""8

The last and most important theme of sustainable development as set out in the Brundtland Report is the "one world" idea which underlies each of the specific institutional and cultural changes which sustainable development will require. It is the idea that ecosystems tie the world's various remote peoples and places together, region to region, province to province, nation to nation. "Ecosystems," notes the Report, "do not respect national boundaries." ${ }^{19}$ As but one example, the Report describes oceans as "marked by a fundamental unity from which there is no escape..."100 No community and no region, no matter how physically remote from the sources of industrialization and resource exploitation, can escape the singleness of the environment. The most recent reminder of this fact is the discovery that toxic PCB's have infiltrated all stages of the food chain in the Canadian Arctic. ${ }^{101}$ The remoteness of Inuit culture, then, has not protected it from the activities of industrialized North America and Europe, the byproducts of which have been carried by rain and snow to the north and can now be traced in Inuit mothers' milk. ${ }^{102}$

How will the recognition of the unified essence of the ecology affect Canadian federalism? Traditionally, it has been argued that federalism is an ideal form of political ordering for resource and environmental management. ${ }^{103}$ This conclusion, however, is premised upon the notion that environmental issues can be characterized as local or national. Scientific research and the painful reality of experience is in the process of exploding the myth that such a line can in fact be drawn. It is in this light that attention is now turned to a discussion of the peace, order and good government clause of the Constitutional Act, 1867 and the issue of whether the dissolution of the local/national line in ecology should prompt a re-drawing of jurisdictional lines in law.

98. These are Ronald Dworkin's words to describe the relationship between present law and the inherent political morality underlying our legal system: Dworkin, "Law's Ambitions for Itself" (1985) 71 Virginia Law Review 173.

99. Brundtland Report, supra note 1 at 38.

100. Ibid. at 262.

101. Canadian Press, "Quebec Inuit worried about PCB's in Milk" Globe and Mail (7 February 1989) A4.

102. Ibid.

103. MacNeill, supra, note 23; Thompson, supra note 57; Saunders, supra note 26. 


\section{PART TWO: ENVIRONMENTAL EXTERNALITIES AND THE PEACE ORDER AND GOOD GOVERNMENT POWER}

As emphasized throughout Part One, the challenge of sustainable development is a challenge to accepted theories of federalism, democracy and the Constitution. The combination of the tenets of sustainable development discussed above bring into question the viability of our present constitutional order. Of the seven tenets discussed, the following three are of particular concern: the institutional requirement that those responsible for managing resources be responsible for related environmental issues, the democratic requirement that there be political accountability of resource managers and that, if possible, areas of political jurisdiction match areas of impact and, lastly, the recognition that the world environment is characterized by a unity which renders political boundaries porous and environmental externalities inevitable.

The precise nature of this challenge can be summarized as follows. To achieve the institutional side of sustainable development, those who manage resource development and those who are capable of being responsible for the environment must be one and the same. This implies either bringing the power to manage natural resources to those who can manage the environment, or conversely, bringing the power to manage the environment to those who manage natural resources. More specifically, in a federal state, the options can be abstractly conceptualized in this way: on the one hand, if jurisdiction over resource management is pictured as fixed in the hands of provinces whereas responsibility for environmental issues is seen as a variable quality, then the responsibility for the environment may be dispersed so as to attach to relevant areas of resource management; on the other hand, if jurisdiction over natural resources is pictured as the variable quality and jurisdiction over environmental issues is seen as the fixed quality in the formula - and, indeed, fixed in federal hands - then, to meet the institutional requirement of sustainable development, control over the management of resources would have to be centralized in the federal government's hands.

Given our past commitment to federalism and the express Constitutional provision for provincial ownership and management of their resources, the latter of the two options the centralized option - seems inconceivable and, consequently, the former option - the decentralized route - appears as the only acceptable way.

This conclusion, however, is weakened significantly once the other tenets of sustainable development are introduced. First, given the unified nature of ecosystems and the increasingly wide impact that resource development has, there will be externalities - and as time goes by, long term externalities will become increasingly more apparent. In short, the decentralized option runs afoul of the fact that local constituencies will be increasingly less capable of fulfilling the responsibility for caring for the larger environmental side-effects of their resource (and industrial) development. More and more resource/environment issues will have to be classified as falling into the second or third of MacNeill's three classes - that is, as cases where the local government lacks the power (because the source of the environmental problem is outside the jurisdiction) or the 
incentive (because the effect of the problem is outside the jurisdiction) to act so as to solve the problem.

If the democratic tenet of sustainable development is then adhered to and the spillover theory of federalism is applied so as to constantly adjust lines of political jurisdiction wider to capture and internalize the environmental externalities as they expand, the national constituency will control ever increasing proportions of jurisdiction previously held by the hands of local constituencies. This is the sense in which sustainable development threatens federalism.

The "Peace, Order and good Government" power of Parliament is the constitutional safety valve which allows for exactly this sort of jurisdictional evolution to occur. It is, in short, the legal incarnation of the spillover theory of federalism, the constitutional vehicle for this theory's operation in law. This conclusion is reflected in the "Watson-Simon"104 articulation of the p.o.g.g. power. Lord Watson describes the transition of power from local to national constituencies in this way:

... some matters, in their origin local and provincial, might attain such dimensions as to affect the body politic of the Dominion, and to justify the Canadian Parliament in passing laws for their regulation or abolition in the interest of the Dominion. ${ }^{105}$

And, Viscount Simon's account:

... if it is such that it goes beyond local or provincial concern or interests and must from its inherent nature be the concern of the Dominion as a whole ... then it will fall within the competence of the Dominion Parliament as a matter affecting the peace, order and good government of Canada, though it may in another aspect touch on matters specially reserved to the provincial legislatures. ${ }^{100}$

Reflected in both statements is the spillover theory: local constituencies should deal with local issues until that point at which the issue attains a national dimension and should be dealt with by the national constituency. Later judicial decisions illustrate that the transition point is marked by the emergence of externalities.

On the surface, at least, this dynamic quality of the p.o.g.g. power can be seen to be particularly suitable as a means of allocating power between two levels of government for resource and environmental issues where problems start locally, fester over time, and then become national. The p.o.g.g. clause is capable of capturing in a legal, constitutional sense the "spatial quality" of the environmental effects of resource management; it is, in short, a mechanism which serves to trigger the correct allocation of power at any given time depending on the degree of environmental externality involved.

104. W.R. Lederman, "Unity and Diversity in Canadian Federalism: Ideals and Methods of Moderation" (1975) 53 Can. Bar Rev. 597 at 606.

105. A.G. Ontario v. A.G. Canada (Local Prohibitions Case), [1896] A.C. 348 at 361-2.

106. A.G. Ontario v. Canada Temperance Federation, [1946] A.C. 193 at 205-6. 
For example, because individual provinces cannot regulate the environmental spillovers which flow in from other provinces by way of transboundary rivers, Pigeon J. in InterProvincial Cooperatives ${ }^{107}$ held that the issue was a matter for federal regulation by virtue of the p.o.g.g. clause. Likewise, the spillover theory of federalism was implicitly at work in the Manitoba Queen's Bench decision to uphold the federal Clean Air Act as intra vires Parliament insofar as it purported to regulate emissions from local industry:

The control of air quality is not a subject of a purely private or local concern. It transcends the scope of provincial jurisdiction. A province cannot legislate to control the quality of air which it receives from an adjoining province or state. ${ }^{103}$

The question as to how far jurisdictional lines will expand so as to internalize within political units the rising phenomenon of environmental externalities is ultimately a question of how far the p.o.g.g. clause will operate so as to open areas of provincial jurisdiction to federal regulation in the name of the environment. In the past, the p.o.g.g. clause has been narrowly construed by the courts, no doubt to prevent, as Professor Lederman says, "any doctrinaire group that wants to push its special cause to the limit" from finding a new label and arguing that the p.o.g.g. clause applies. ${ }^{109}$ Today, the clause may be invoked to deal with three different scenarios: first, national emergencies, second, new matters not existing in 1867 and which cannot be said to be local matters and, lastly, matters which, though originally considered local, now go beyond provincial ability to regulate and, from their inherent nature, are national. ${ }^{110}$

Federal environmental legislation purporting to regulate the management of local industry and provincial natural resources could, of course, be supported as emergency legislation. As Professor Gibson notes, however, "the courts are not likely to cry emergency as often as ecologists". 111 More likely, federal legislation will be argued to fall under the last category, of which emergencies are perhaps just a special example.

To qualify as a matter which evolves from being purely local in nature to one capable of attracting federal regulation under the p.o.g.g. clause, the matter must undergo a transition into one of national concern. According to Beetz $\mathrm{J}$. writing in the Anti-inflation case, it must "meet the test of singleness or indivisibility", it must not merely be "an aggregate [of local matters] but [it must have] a degree of unity that made it indivisible,

Re Canada Metal Co., supra note 33 at 129.

Lederman, supra, note 104 at 615.

Estey J. in Labatt Breweries of Canada, Ltd. v. A.G. Canada, [1980] 1 S.C.R. 914.

Gibson, supra, note 20 at 84-85. No doubt, the Inuit consider there to be an emergency (see supra, note 101); and it seems only a matter of time before this problem is national in scope. If so, could Parliament pass emergency legislation to prevent a crisis? The decision in the Local Prohibition case indicates that this is possible, supra, note 105. 
an identity which made it distinct from provincial matters and a sufficient consistence to retain the bounds of form ...."112

Do environmental matters have the requisite singleness and indivisibility so as to trigger the operation of the p.o.g.g. power? In essence, the question concerns whether the scientifically recognized unity of ecosystems translates to the sort of unity recognized in law as attracting federal regulation. As mentioned, the environmental aspects of interprovincial rivers and air have been accorded this status. Furthermore, the most recent Supreme Court of Canada decision in this area in Crown Zellerbach ${ }^{113}$ can be seen to support the proposition that, indeed, "unity" in law equates to "unity" in the scientific sense of interlocking ecosystems.

The Supreme Court of Canada's decision in Crown Zellerbach not only stands as the most clear judicial enunciation of the spillover approach to the p.o.g.g. clause but, in a broader sense, the majority and minority judgments effectively capture the essence of how the principles of sustainable development challenge Canadian federalism. The case arose when the federal Ocean Dumping Control Act, ${ }^{114}$ which purported to prohibit the dumping of any substance in ocean waters without a permit, was challenged as being ultra vires insofar as it attempted to regulate the alleged dumping in this case. The alleged dumping had occurred within British Columbia's waters. It could not be shown to affect the fish environment and, hence, the Fowler test ${ }^{115}$ could not be invoked so as to justify the Act under the federal fisheries power. Furthermore, the effect of the dumping could not be shown to transverse provincial boundaries so as to constitute an externality and, hence, the case did not, strictly speaking, fall within the Interprovincial Co-Operatives logic. In sum, the matter appeared to be a local one in relation to the provincial management of its forestry resource. Notwithstanding this appearance, LeDain J., writing for a majority of the court, found ocean pollution to constitute a matter with a national dimension and a "singleness" and "indivisibility" necessary to attract federal regulation pursuant to the p.o.g.g. clause.

In determining whether the matter of ocean pollution had the requisite singleness and indivisibility, LeDain J. applies the spillover theory of federalism - or, in his words, the "provincial inability" test. He asks whether a "provincial failure to deal with the intra-provincial aspects of the matter could have an adverse effect on extra-provincial interests". ${ }^{116}$ In answering this question, LeDain J. does not rely on the facts of the case, there being no proven environmental externality, but rather he recognizes, at least implicitly, the scientific, ecological unity of oceans and equates this to a legal, constitutional unity for the purposes of the p.o.g.g. clause. "Marine pollution", he

\footnotetext{
112. Re Anti-Inflation Act, [1976] 2 S.C.R. 373, per Beetz J. at 458.

113. Supra, note 34.

114. S.C. $1974-75-76$, c. 55.

115. Supra, note 37.

116. Supra, note 34, per LeDain J. at 434.
} 
concludes, "because of its predominantly extra provincial as well as international character and implications, is clearly a matter of concern to Canada as a whole". ${ }^{17}$

The question which was posed at the end of Part One of this paper was whether any sort of pollution, any development of a natural resource, or any industrial project cannot now (in light of scientific revelations) be said to have "extra-provincial as well as international character and implications". In his dissenting judgment in Crown Zellerbach, LaForest J. shows that he is acutely concerned with this very question. Pollution control, he notes, "is incidentally only part of the even larger global problem of managing the environment;" ${ }^{118}$ and this, in turn, implies managing industry, resources and, in the end, "[a]ll physical activities". ${ }^{119}$ If all matters having environmental externalities are placed within Parliament's legislative competence there will be, says LaForest J., "profound implications for the federal-provincial balance mandated by the Constitution"..$^{120}$ In order to limit this potentially all-encompassing federal head of power, LaForest $\mathrm{J}$. narrowly construes the spillover requirement of the p.o.g.g. power and holds that in the absence of some proven provincial externality, federal jurisdiction will not be triggered. At the heart of his dissenting judgment, then, is the desire to protect traditional provincial resource management powers: "I cannot accept that the federal Parliament has such wide legislative power over local matters having local import taking place on provincially owned property". ${ }^{21}$

When juxtaposed against each other, the majority and minority judgments in Crown Zellerbach capture the essence of the constitutional dilemma created by the emerging environmental concerns of today. Both are sensitive to the ideas which underlie the Brundtland Report: on the one hand, LeDain J.'s judgment stands for a judicial recognition that environmental matters are characterized by a unity which defies attempts at encapsulation as local matters; on the other hand, LaForest J.'s judgment stands for the proposition that notwithstanding the scientific singleness and indivisibility of environmental matters, on a legal dimension, our past commitment to federalism demands the conclusion that the responsibility for environmental management must follow the constitutional powers over local industry and resource development, namely, it must rest with provincial legislatures (unless the externalities are patently obvious).

This discussion of the p.o.g.g. clause illustrates that under extreme assumptions namely, that all resource development within provinces will lead to extra-provincial environmental problems - the logical extension of the spillover theory of federalism is to allocate to Parliament the legislative competence to regulate all environmental issues. The theoretical effect of this is to fragment constitutionally resource development

Ibid. at 436; in this conclusion, LeDain J. echoes the Brundtland Report's statement on ocean: supra, note 100.

118. Ibid. per LaForest J. at 447-8.

119. Ibid. at 454.

120. Ibid. at 448 .

121. Ibid. at 459 . 
decisions from environmental responsibility. This violates the "chief institutional challenge" of sustainable development. Given the extent to which resource management is constrained by environmental concerns, however, the practical effect may be to shift large portions of provincial jurisdiction over resource management to federal hands. This is in violation of the Constitutional commitment to federalism.

In short, the general dilemma which environmental concerns create for federalism is played out constitutionally under the p.o.g.g. clause. When driven by the spillover theory of federalism, the p.o.g.g. power, as applied to resource management and environmental issues, takes on a meaning which runs counter to the general direction of the Constitution as a whole. Although the general fabric of our Constitutional order is permeated by centralist and regionalist tensions, in this instance the effect of the "spillover" conception of the p.o.g.g. clause is to take the strong weight of express language in favour of a large provincial role in resource management, namely, sections 109, 92(5) and 92A, out of consideration. In other words, given that the unity of ecosystems will become increasingly more apparent, the provincial inability test as defined by LeDain J. in Crown Zellerbach will offer a low threshold before the apparently strong textual provision for provincial power in this area is constrained by the general power of Parliament. As Professor Simeon notes, the danger of the spillover theory of federalism is that it generally tends toward centralization of power. ${ }^{122}$

The converse side of the dilemma is the effect of a more restrained reading of the p.o.g.g. clause. For instance, the legal standard of "singleness" and "indivisibility" could be defined more narrowly than the mere existence of the physical singleness which characterizes the environment. A more onerous burden could be placed on the Parliament to demonstrate some serious provincial externality actually exists before its legislative competence under the p.o.g.g. clause is triggered. From the perspective of sustainable development, given complexity of causes and effects in the context of the web of linkages which characterizes ecosystems, the burden of proof may be difficult to meet in law and, consequently, a national goal of sound environmental planning may be thwarted by the parochial interests of a locality.

To summarize briefly, it may be helpful to return momentarily to the "formula" described at the outset of Part Two. Apparently, resource management is constitutionally fixed in the hands of provinces. Under the spillover theory of p.o.g.g. however, an increasing degree of environmental matters will become fixed in the hands of the federal Parliament. If neither resource management or environmental management is a "variable", resource and environmental decision-making is fragmented between governments. In other words, the federal ideal in our Constitution may inhibit the attainment of sustainable development's institutional tenet. 


\section{CONCLUSION}

In discussing the constitutional implications of the seven tenets of sustainable development drawn from the Brundtland Report, it was seen in Part One how environmental challenges of today raise unique problems for federal states. The discussion in Part Two demonstrated that, on a legal dimension, the "Peace, Order and good Government" clause of the Constitution Act, 1867 will be the focal point around which the resulting constitutional dilemma will be resolved.

The conclusion reached at the end of Part Two is, however, suspect on a variety of counts. First, the picture drawn as to the potential scope of the federal environmental power under the p.o.g.g. clause, while theoretically sound, is an exaggeration of reality. LeDain J. in Crown Zellerbach is careful to limit the extent of the federal power under the p.o.g.g. clause to the extent of the provincial inability. If provincial legislatures are as committed, or more committed, to the goal of sustainable development than Parliament, there may be no reason to invoke the p.o.g.g. power at all.

The conclusions in Part Two may be artificial on a further count. Even if provincial inabilities persist and create environmental externalities, the "political constitution" will no doubt serve to prevent Parliament from unilaterally exercising its full legal authority.

Finally, the conclusion reached above, that once the full extent of environmental externalities are fully realized, Parliament will have legislative authority over all issues of environmental management whereas provinces will retain legislative, and proprietary, authority over resource management is, as hinted earlier, from a practical standpoint, impossible. The two matters, environment and resource management, are ultimately indivisible. Professor Lederman came to this conclusion in his examination of some of the anomalous issues which simply fail to fit into the federal division of powers. Problems like the environment, he concluded, "should be treated outside the system", that is, they should be addressed by both levels of government through "cooperative federalism". ${ }^{123}$

In short, for both practical and theoretical reasons, the only way in which resource development and environmental decision-making can occur simultaneously so as to prevent the institutional fragmentation the Brundtland Report criticizes is through federal-provincial cooperation. As noted in Part One, this is how environmental management is coordinated today. And, as noted at the outset, the National Task Force on Environment and Development, without even mentioning the issue of potential constitutional conflicts over jurisdictions, premises its recommendations concerning the development of a network of government-industry "Round Tables" on sustainable 
development on the assumption that "inter-jurisdictional cooperation" is the key to a "national conservation strategy". ${ }^{124}$

Likewise, the scope of federal environmental regulation under the Canadian Environmental Protection Act ${ }^{125}$ will be determined, at least in part, by federal-provincial advisory committees aimed at "establishing a framework in national action and taking cooperative action in matters affecting the environment and...avoiding conflict between, and duplication in, federal and provincial regulatory activity..." ${ }^{126}$ The CEPA is therefore a legislative articulation of cooperative federalism. ${ }^{127}$

The conclusion that cooperative federalism is the key to sustainable development leads back to one of the initial questions of this paper, namely, that concerning the normative force of the Constitution Act, 1867 in relation to the new context of sustainable development. Must it be concluded that the Constitution can offer no guidance? While cooperation between jurisdictions may be the key, the nihilistic assumption that the Constitution is thereby rendered a mere bystander in the process is troubling. As emphasized in Part One, sustainable development requires both public visibility and accountability of policymakers. If, as has been argued, the current regime of cooperative federalism fails in this respect, the ultimate challenge may be in finding a remedy. It is in this sense that the Constitution can play a constructive role. Constitutions may not always provide comprehensive answers to problems, however they can, as Professor Ackerman notes, provide "the language and process within which our political identities [can] be confronted, debated and defined..." ${ }^{128}$ A reading of the Constitution in light of both the reality of federalism and the ideal of sustainable development can provide well defined Constitutional responsibilities for provincial and federal governments. While these spheres of responsibility may not be amenable to unilateral action by one or other of the relevant legislatures, the Constitutional definition of their parameters is a prerequisite to a regime of cooperative federalism in which room is made for effective participation by an informed public.

Of course, this conclusion of cooperative federalism does not help courts settle disputes in a litigation setting in which an "all or nothing" decision must be made. Thus, "[t]he challenge for the courts", says LaForest J., "as in the past, will be to allow the federal Parliament sufficient scope to acquit itself of its duties to deal with national and international problems while respecting the scheme of federalism provided by the

124. National Task Force on Environment and Economy, Progress Report (Canadian Council of Resource and Environment Ministers, October, 1988) at 6.

125. Supra, note 5 .

125. Subsection 6(1) of the CEPA.

127. For a discussion of the constitutionality of the Canadian Environmental Protection Act in light of the Crown Zellerbach decision, see Marcia Valiante, "Annotation to R. v. Crown Zellerbach" [1989] 3 C.E.L.R. (N.S.) 3, and Alastair Lucas, "R. v. Crown Zellerbach Ltd." (1989) 23 U.B.C. Law Rev. 355.

128. Bruce Ackerman, "The Storrs Lectures: Discovering the Constitution" (1984) 93 Yale L.J. 1013, at 1072. 
Constitution". ${ }^{129}$ When future constitutional challenges of the Crown Zellerbach sort arise, the tendency of the courts will be, as LaForest J. says, to express the solution in terms of balancing national environmental concerns with federalism. In the adversarial context of litigation, a "winner" will have to be declared.

It should be remembered, however, that to phrase the issues in this way is to commit the conceptual error which the Brundtland Report seeks to end, namely, the attitude in which sound environmental policies are seen as obtainable only at the expense of other institutions and activities which we value. Just as economic development cannot be conceptualized as the price of the environment, neither can the ideal of federalism. In the long run, both the idea of economic development and the idea of federalism become empty of meaning without the presence of a physical world worth living in. This is perhaps just another way of saying that, ultimately, there is no challenge to federalism by the need to institute strategies of sustainable development as long as both local and national dimensions in our federal state recognize and pursue the same end - namely, the use of natural resources today in such a way so that a world is left which can sustain life tomorrow. 